\title{
The Nature of Track Three Diplomacy and its Influence on Cross-Border Security Relations between Kenya and Somalia
}

\author{
Stella Wasike (PhD Candidate) \\ Masinde Muliro University of Science and Technology, Kenya \\ Prof. Pontian Godfrey Okoth (Lecturer) \\ Masinde Muliro University of Science and Technology, Kenya \\ Dr. Edmond Were (Lecturer) \\ Kisii University, Eldoret, Kenya
}

\begin{abstract}
The complexity of interstate and intrastate conflicts has become a critical challenge to the field and methods of conflict resolution. Diplomacy has been a paramount element in the upkeep of peace and in the creation of positive change since the peace of Westphalia. Nowadays, one talks of many tracks of diplomacy without diplomacy, much of the world's affairs would not exist. Diplomacy represents the most powerful tool that is possessed by every county in the fight against modern forms of insecurity that have expanded beyond state boundaries. In trying to find the best methods of resolving conflicts, a variety of types of diplomacy have been identified. The most common forms of diplomacy in conflict resolution are Track One, Track Two and multi-track diplomacy. This paper presents Track Three diplomacy which has been overlooked by most leaders in the world. It is also referred to as people to people diplomacy. It is a diplomacy at the grassroots level, which creates better understanding of the other, promotes tolerance and feeds a culture of peace among citizens. The paper specifically demonstrates the different forms of Track Three diplomacy, security issues along the border region, actors involved in this type of diplomacy and how it has contributed to the management of the insecurity between Kenya and Somalia. The paper further recommends hat world leaders adopt this form of diplomacy since it has proved to be effective as the local community is directly involved.
\end{abstract}

Keywords: Track Three diplomacy, Diplomacy. Cross-border, Security. Security relations. Grassroots level

\section{INTRODUCTION}

The lack of people's involvement in the struggle to build a new social order makes any peace-making process unstable, fragile and vulnerable. Track Three diplomacy is therefore an initiative that operates and mediates in the field within a divided society, trying to reconcile it. It does not aim specifically to resolve the wider conflict but instead focuses on the concepts of contact and understanding as a way of setting the table for resolution (Thornton, 2003). In other words, it is not designed to change the very nature of the troublesome conflictual relationships. It is also not designed to bring together contending parties to negotiate for equal pieces of the pie. Rather, participants probe the dynamics of contentious relationships that cause problems. The participants then gradually develop a capacity for designing actions to change those relationships (Saunders, 1999).

This form of diplomacy represents the most profound force in promoting security. For instance, security relations between the US and Taiwan has improved and Track Three diplomacy has played a stronger role in enhancing overall ties (Da-Jung, 2010). Besides, Track Three diplomacy played an important role in the US-Soviet relations when the American business executive Arm and Hammer played an important role by encouraging trade relations between the US and the former Soviet Union during the Cold War era (McDonald, 1991).

Track Three actors represent a dense array of grass roots groups, enlightened persons, cultural minorities, networks and popular movements who have marginal clout on decision making power and are unable to achieve requisite social change without external help. This track tries to influence indirectly by transitional media advocacy, lobbying and citizen activism. Conflict transformation at the grassroots level lies with the peoples and communities directly affected by it (Lederach, 2003). 
Track Three diplomacy has been embraced by a few countries. For instance, in the India-Pakistan cross-border security relations Track Three diplomacy was initiated by individuals and groups within the civil society. The objective was to promote mutual understanding through people to people contacts, to diffuse existing and latent tensions by creating an informed public opinion and to use public pressure on governments to restructure their relations (Ahmed, 1998). It should thus be noted that when cross-border security relations at the top remain lukewarm, at best Track Three diplomacy initiatives are essential. People exchange at the grassroots and after all, it is the ordinary people that form the foundation of a strong and rather durable cross-border security relationship between countries (Ahmed, 1998).

Track Three initiatives are partly responsible for the extensive enhanced cross-border security relations between the U.S and Mexico. (Bosworth et, al., 1997). The close interactions between the local people and local governments from the two sides of the border has enabled the two countries resolve some of the security issues between the two countries ranging from combating narcotics trafficking to protecting the shared environment (Bosworth et al. 1997). However in the Japan-China security relations, the power of Track Three diplomacy is woefully under-utilized. The two countries assume that only their national leaders and politicians matter in international relations. Such perspectives overlook the power of Track Three diplomacy and are therefore detrimental to improving their cross-border security relations (Zhu, 2015).nevertheless, contrary to Zhu, the two countries have now realized the importance of enhancing Track Three diplomacy, especially among the young. For instance, early 2016, the Japanese embassy in Beijing co-sponsored Japanese speaking and writing contests in China and invited young Chinese to visit Japan. In addition, paintings of artists from both states were on display early 2016. Therefore, more such cultural activities at the local levels are needed so as to enhance security relations between the two countries.

Actors in Track Three engage in various activities and do not engage with any government. The rich mix of ideas among people offers new opportunities, synergies and formulas for addressing global problems (Handelman, 2012). Track Three initiatives are often ignored or given minor coverage by the official press which often dominates the media landscape (Payne and Sarah, 2006). However, this is not true since some countries such as the US, Canada, Mexico, just to name a few, have publicly encouraged Track Three diplomacy as one of the best initiatives of enhancing security relations in their official forms of the press. Besides, such countries understand the power of people. In addition, apart from the official press, other alternative media channels that are less controlled by the government and the dominant discourse such as blogs, Short Message Service (SMS), social networks, just to mention a few, have been used by a majority of people as a means of communication and they provide a lot of essential information as regards Track Three diplomacy. .

Track Three requires people to people interactions involving creativity, compromises and innovation of brave individuals and groups who have refused to surrender in their struggle for peace. Its efforts are manifested through different structures, initiatives and programs seeking to bring people together in order to give a human face to the other and hopefully generate sufficient momentum and pressure from below to bring about the long overdue political will to move forward towards a peace agreement (Shemesh, 2012). For example, the signing of the Oslo Peace Accords gave scope to a multitude of Track Three initiatives which sought to encourage ordinary Israelis and Palestinians to better understand one another and thereby to initiate processes of mutual reconciliation (Atieh, et al, 2004).

According to Atieh et al (2004), Track Three diplomacy's role in facilitating real change is undeniable and irreplaceable. Atieh et al (2004) further note that this track is indispensable since mutual reconciliation is crucial to a peaceful settlement of the conflict, and such reconciliation can only be achieved through the people themselves. Since peace requires a profound mental shift on both sides, the deliberate, concrete efforts of groups and individuals working together to reshape the society are necessary (Atieh et al, 2004). Nevertheless, people's efforts have not always led to reconciliation. There are several instances when Track Three initiatives have been employed in the reconciliation process but this has been unsuccessful. For instance, in spite of the interventions by Track Three in the security relations between Chad and Sudan border, this border is still considered as one of the insecure borders in Africa.

According to McHale (2009), engaging with people ensures the stability and security of the world. In addition, connecting between people and establishing dialogue is the key to influencing relationships, for example, through the use of social media platforms where the people lead the Track Three 
diplomacy efforts. This formula was proven to be productive and highly successful during the last round of violence along the Gaza border and has since become the foundation of Track Three diplomacy in major national public operations. These platforms represent the voice of the people (McHale, 2009).According to Mngqibisa (2000), states are often misplaced to engage in or coordinate community-based peace building. He further states that through state-based institutions, a violent culture may be perpetuated.

\section{Track Three DiPlomacy Along The KenYA-Somalia BORDER}

Track three diplomacy is said to be horizontal or vertical on the basis of the type of integration done.

\subsection{Horizontal Track Three Diplomacy}

This type of Track Three diplomacy entailed the people to people intervention which cut across different identity divides. The Track Three interactions were between members from both Kenya and Somalia in the context of the security threat or conflict. Those involved in this type of Track Three diplomacy were either middle range contacts who act as a link between adversary groups, or between the top government officials and the grassroots contacts. It also involved the grassroots contacts who worked with the grassroots members.

Middle range contacts act as a link between the grassroots participants and the national governments, or between the adversary groups. There were many ways through which this has been done. One way was that when there was a dispute between adversary groups, in the effort to try to reach an amicable solution, the Track Three middle range contact separately approached the adversary groups. The members do not have a face to face meeting in the initial stage. Instead, the middle range contacts take messages across the groups. The groups only meet after each party has agreed to come to the negotiating table. The Track Three middle range contacts in this instance play a critical role in bringing peace between the groups.

This form of Track Three intervention also entails finding avenues of cooperation between local leaders or local professionals from different sectors within the conflicting communities to build a peace constituency. These contacts are also middle range contacts since they neither belong to the national government nor the grassroots. These professionals are quite instrumental as they strengthen the capacity of middle range peace builders. They do the groundwork and create the base on which the whole structure of Track Three has to be constructed. These professionals from different communities sit on a common platform, hold dialogues and devise programs for promoting peace and understanding between their communities. Their activities include inter-group contacts between second-tier leadership within conflicting communities to derive strategies and programs for promoting peace. Such middle range contacts include face to face meetings or through telephone or the internet among themselves.

Generally the essence of such events spearheaded by the middle range contacts is to build intercommunity relations at the larger middle range so that the communities as a whole could be transformed. This form of diplomacy is meant to change relationship at the level of second tier leadership and make a contribution by building peace constituencies among conflicting communities. There are also professional platforms in media houses whereby the professional groups share common interests in building links by cross-cutting their identity divide and as such, they are well placed to bring constructive social change. For instance the Track Three networks between traders and businessmen of adversarial communities help create a vested interest in peace for the two communities. It was generally deduced from the field findings that horizontal middle range Track Three interventions played an important role in building a strong team of peacemakers who could later design and implement interventions to integrate the grassroots level with the top level of the national governments.

When this form of diplomacy involved grassroots contacts, this was very important since it helped connect the adversarial communities at mass level by engaging them in direct interactions cross cutting the identity divides in the conflict zone. Such interventions were easier to organize since adversarial communities lived side by side. During such interventions, common people and local leaders take part. Grass roots communities are involved in the peace process. They are empowered to have their voice heard and connect them with the highest level of negotiations. Most of the grass roots interventions were designed and organized by the middle range leadership with the cooperation of the 
local leaders. There were two types of grassroots interventions. One was that intervention for which participation of people was restricted. It was not open to the common people. This type of intervention was regarded as closed grassroots track three diplomacy. The second type of intervention was referred to as open grassroots track three diplomacy whereby participation was open to the common public creating local platforms and engaging local communities in peace building.

During closed grassroots Track Three diplomacy, participation of people is restricted to only a few individuals. It is expected that the participants take the message along and convince the communities about peace. Such interventions have three features, namely, peace meetings, discussion forums and dialogues. During peace meetings, facilitators inform participants about the security threats in the region and on measures of how to curb such security threats. The meetings are organized at troubled places. The language of communication during the meetings is vernacular. During such meetings, sometimes peace agreements are signed between the warring communities. The agreements are varied, ranging from agreements on peaceful resource sharing, to those of peaceful co-existence and even others involve giving up the illicit arms.

Another feature of the closed grassroots interventions are discussion forums. During such forums, the participants are given a chance to air their views or suggestions about any issue that would have been brought to the attention of the participants. Resolutions to the prevailing security threat are made by the participants themselves, who then relay the resolutions to the other community members. These forums are always free from any politics. Sometimes, the media is always invited to air these discussions. The language of communication is mainly vernacular in order to make the participants speak with ease. It also enhances better comprehension by other members who would have not participated when the discussion is replayed by the media at a later time.

These forums were held to identify real security challenges on the ground, mark out means of grass root mobilization and awareness towards a solution. The forum had good will of the government as this was realized through the attendance of government officials. During the discussions, a follow-up working group was formed to ensure that regular deliberations on matters identified are done as well as undertaking training on issues of tolerance and peaceful living. Nevertheless, the challenge with these closed grassroots interventions, was that the effect that they had on those who had not taken part in the events, did not fully materialize. This explained why there was a lapse in the implementation of the decisions that had been arrived at during these events.

The other form of horizontal interventions is the open grassroots Track Three interventions. These interventions played a key role in linking communities to the top level peace processes. They generally made a good use of activities such as music, art, sports and culture to promote peace among grassroots. Moreover, some time-tested nonviolent techniques were also used such as peace marches, peace rallies, peace caravans, joint day celebrations and they were quite effective in this regard. Besides, it was also established that in this age of information revolution, face book, twitter, FM radio and the private TV news channels provided a chance to invent and try new innovative techniques to open grassroots interventions.

\subsection{Vertical Track Three Diplomacy}

This form of diplomacy comprised of people to people contacts which tried to build peace by integrating the lowest level of the society to the top level. The connection between the top level and the lowest level was done by what can be referred to as second-tier leadership who comprise of either professionals, religious leaders who were not local, businessmen or leaders respected in various sectors. The meetings were between these peace workers with the top level leadership in government.

What was involved in this case was that this second tier leadership of the two adversary parties would sit on a common platform with the top level leadership hold dialogues and devise programs for promoting peace and understanding between their communities. They did this through activities such as face to face meetings or through phone or through the social media between themselves. There were three approaches that were employed in order to build peace. First they organized problemsolving workshops, which featured informal meetings that were designed to broaden participation and deepen the parties' understanding of their shared problems. They also provided forums for effective interactions as well as a politically safe space to test new ideas.The second approach, was the conflict resolution training which aimed to raise parties' awareness about how conflict operates and to impart skills for dealing with the conflict. The second tier leadership was normally brought together in 
training sessions to share their perceptions of the conflict, analyze their own roles in it and develop approaches that would promote reconciliation.

Finally, this leadership participated in peace commissions or peace committees that allowed for increased communication at the international, national level, regional and local levels. These commissions brought prominent people from each side of the conflict and they all worked towards reconciliation. On this, the study was informed by one man who was a peace committee member in Dadaab that the Kenyan government had partnered with these peace committees in the region and as a result, they have succeeded partially in reversing the insecurity in the area. The committees have succeeded due to a good functional relationship with the Kenyan government, which has generally given these peace committees adequate space and autonomy to operate.

Activities in this vertical Track Three diplomacy included peace meetings, conventions, performances, campaigns and such activities required careful planning, continuous hard work, and full commitment to integrate the grassroots communities to the peace process.

It was however established by the researcher that within this region, vertical interventions went unreported and did not get proper documentation because the media and peace activists themselves focused mainly on the horizontal interventions and considered the vertical interventions least important.

Generally, these Track Three interventions were more enhanced on the Kenyan side of the border than the Somali side. The interventions on the Somali side were weak and they completely lack the support of the Somali government. This lack of support is attributed to the weak Somali government which is so much immersed in dealing with the many state issues. In addition, the Track Three structures such as peace committees were more established on the Kenyan side and they receive funding from the Kenyan government or other donor agencies. These structures are lacking on the Somali side. Instead, Somalia relies basically on the structures in Kenya. They are these Kenyan Track Three structures that have been responsible for part of the durable peace in the region thus stable cross-border security relations.

\section{ACtORS in Track Three Diplomacy BeTWEen KenYa AND SOMALIA}

There were several factors involved in managing bilateral security relations between Kenya and Somalia. These actors have either had a positive or negative impact on the bilateral security relations. The actors included top level actors who comprised of the political or government leadership which represented fewer people. Their role was basically to advance political negotiations among elites and implement accords. They played an integral role in the transition to peace. They constituted security officers, key political, government and top religious leaders, who are the primary representatives of their constituencies and are highly visible. Their role was thus to maintain an image of strength and so they had to only act by their set goals.

For instance, the top religious leaders have dealt with ideological differences. They have been taking a leading role in establishing voluntary organizations, whose mandate is to coordinate the development of a modern Islamic education and institutions offering this type of training in the region. These leaders have generally assumed a facilitative role, bringing together elders, and religious leaders, international and national organizations and have even sponsored cross border dialogues.

The security agents have worked closely with the community members and also the second tier leadership to see to it that there is peace and security in the region. Some security agents have even given their numbers to the community policing units to report any suspicious criminal cases to them. They have also worked with community members and local leaders towards disarmament and also counter any al shabaab militia in the region. They have in certain instances made arrests of bandits.

On the other hand, the middle range actors have functioned in leadership but were not connected with the formal government. Their status and influence was derived from their relationship with other leaders from sectors such as education, business, agriculture, commerce and health. They served as an important connection between the top and grassroots level actors. These actors thus included successful business people, NGOs which deal with humanitarian services and professionals from the region. Some humanitarian assistance NGOs had also played a major role in managing peace and security in the region. For example, they have contributed funds to facilitate Islamic religious leaders 
for peace talks. Some have also trained mediators on the ground, the main result being dialogue among communities.

For instance, in Dadaab region, there is the Finn Church Aid (FCA) Organization which has worked closely with the The Abdwak and Aulian communities since 2014. The organization has held meetings with elders from these communities and stakeholders and also more women and youth. In one meeting held in April 2015, the elders in the presence of FCA organization declared their readiness and willingness to discuss root causes of the dispute. Religious leaders through SUPKEM Garissa Branch led communities in settling the contentious issue of cattle rustling.

Other NGOs have strengthened the capacity of women for peace and peace committees with financial assistance. They have brought in external consultants to train trainers with a view of building local expertise to trauma counseling. The training targeted teachers, chiefs and NGO workers, who would use the skills in their localities.

Professionals from the regionhave facilitated consultative workshops with stakeholders in Garissa They have been active in intervention processes. For example, between 1992 to 1993 when a conflict erupted in Wajir, a group of educated professionals decided to intervene and this led to the formation of the Wajir Peace Group (WPG), with members from all clans within the county and even across the border. The professionals have initiated dialogues through the traditional processes. In Garissa for example, some urban elites came together and formed PPDI in 1999. This Peace Group was involved in fundraising money towards funding for peace following a conflict between the Somali Auliahan and Abdwaq clans in Garissa, in 1998.

The grassroots actors represent masses, who experienced a day to day struggle. They bring together former enemies at the village level and they are a crucial group toward reconciliation. They normally witness first hand deep-rooted hatred and animosity associated with conflict. According to Wilson (2001), these actors are locally based individuals who are well positioned to address matters of community building and identity formation. They are therefore in close proximity to each individual, which builds trust, respect and confidence between those involved in the conflict. The actors included community members themselves, especially women and the youth leaders, community elders, members who worked in local NGOs and CBOs, local religious leaders, aid workers, refugee camp leaders, and local peace committee workers.

The local NGOs and CBOs have been remarkably active in the region, especially on the Kenyan side. The NGOs and CBOs on the Kenyan side of the border form a vibrant network. They basically review security on a daily basis. The NGOs and CBOs have spearheaded the signing of peace accords between cross-border and local communities. For instance, in 2001, the AlFatal peace organization held a meeting with the District Peace and Development committee in Wajir and discussed on how to enhance security in Mandera, Garissa, Samburu, Isiolo and Marsabit counties. This culminated in the signing of the Modogashe Declaration. Another local NGO in the region is known as Cordaid, which works with local partners and communities and supports peace building activities in order to curb SALWs in the region. However, NGOs and CBOs on the Somali side are not so much active. Their role in ensuring peace and security in the region is not so steady due to the high level of insecurity in the region. Most of them have closed down for fear of being attacked by al shabaab. However, there were some NGOs and $\mathrm{CBOs}$ that were still operational in the region. Their actions include negotiation, facilitation and mediation. These NGOs have built strategies to increase the capacity of civil society organizations, including women's groups, elders, youth and students.

On the other hand,the elders use their position of moral strength to find an acceptable solution to security issues between Kenya and Somalia. Though they cannot normally end violence but they do make an important contribution towards a wider peace. The decision of elders carries the foresight that ensures social harmony.

The community elders commit much speedier and more effective blood payment for crimes committed and much greater penalties on kinsmen who resort to revenge killings. The authority of the elders and the customary law 'xeer' was partially undermined in both Kenya and Somalia through colonial and post-colonial state manipulation. However, the revival of the authority of elders and the customary law along the border has been the single most important source of security and conflict management since 1990. The elders act as authoritative representatives of their clans in peace negotiations and their role as quasi-diplomats managing relations with neighboring clans and in 
adjudicating or mediating disputes within their lineage has been largely unquestionable since the civil war of 1992. On the Kenyan side, the elders have used the customary law to manage security issues in the region. These elders have also been effective outside mediators in peace talks. The elders and the customary law have been crucial to managing security relations between the two states. They function as a court with broad and flexible powers to interpret evidence, impose judgments and manage reconciliation.

The local residents have also come up with agreement mechanisms that address the threat of insecurity along the border. For instance, the Maikona/ Dukana peace accord promoted harmony among the pastoral border communities. There is currently a low number of physical violence since this agreement was made. Its terms promote peaceful resource sharing and cordial relations among communities, as opposed to competition and violence. There have also been community driven protection initiatives by the local residents. For example community members in Kambioos camp decided to install solar lights to make the streets of the camp safer at night. This was done by community teams composed of a wide variety of camp inhabitants, including women who head households, elders, the disabled, youth, business people and religious leaders. Besides, in several towns along the Kenya-Somalia border, there is more cosmopolitan identity, in which the residents generally view themselves primarily as citizens of that town. This has reinforced local solidarity and peace on either side of the border. In 2012, residents of Ifo camp handed over to the police a bombmaking equipment they had discovered.

Local leaders have been quite essential in enhancing security within the border region. These leaders have facilitated cross border meetings, bringing together elders, religious leaders and even community members for cross border dialogues. Quite often, they have held consultative meeting with community members from either side of the border, in order to address the insecurity in the region, and to chat a way forward towards peaceful management of the security issues in the area. This has as a result seen some reduction in violence.

In addition, the local administration in the area plays an important role in partnering with local communities in cross border diplomacy. For instance on the Kenyan side, the County governor of Garissa engages in cross border diplomacy that reflects local clan priorities. The local leaders have also on several occasions attended discussion forums on radio stations, which have been held to identify security challenges on the ground and map out means of addressing them.

Aid workers, all from Kenya and Somalia ensure the smooth running of the refugees' and IDPs' life within the camps. They provide foodstuffs, water, sanitation and basic health care to the refugees and the IDPs. They also offer counseling sessions to traumatized refugees and IDPs and advise them to keep off violence as this would affect their livelihood within the camps.

Youths leaders in Kenya, have played an instrumental role in improving the security situation in the region. Through their youth groups, these leaders provide forums for exchange of views and ideas for the youth. These youths also campaign against drug abuse which is the driving force behind committing crimes in the region. In Elwak, there is a youth resource center which serves youths from both sides of the border. The center offers training and cheap photocopying online courses, discussion forums, and recreational facilities. This center also assists illiterate youth seeking employment. The center has assisted illiterate youth with job applications as watchmen. The youths also talk to their peers and urge them to give up illegal activities, such as engaging in terrorism. They urge them to give up the illicit arms they possess. They also advise their peers to work closely and cooperate with other members of the community, for the sake of enhancing security between the two countries. Some youths are also involved in Community policing in order to manage security issues in the region. The youth have also engaged in joint youth activities such as sports. This has enhanced interaction between these youth, making them focus on management of peace in their region.

Women generally understand impacts of war and absence of peace and what it inflicts to people, since women and children bear the greatest burden when a country is confronted with volatility. Women have been significant in managing security in the region. Their key function is the communication among its members in order to decrease tensions. Between 1992 to 1993, a small women's civic group helped set in motion a peace process which eventually culminated not only in a relatively durable peace among the three main clans on either side of the border in Wajir but also produced a new type of civic-government partnership for security management, that went on to become a model 
for peace committees along the whole border region of Kenya and Somalia. According to the narration by one woman, the chairperson of Together Women Group in Ifo:Anran Abdundi, a woman in 2014, staged rescue missions along the border to save women and children from the danger posed by the presence of al shabaab and other armed militia groups in the region. She used her organization, The Frontier Indigenous Network, to mobilize other women peace builders and rights activists to reach the emaciated and hunger stricken vulnerable population by setting up shelters along the border. Her organization initiated a process of engaging stakeholders in addressing SALWs, as a way of reducing violence and also stopping rape within the conflict. This process led to drafting of a regional master plan on SALWs, which established a working formula between civil society actors and government agencies. Local communities also got involved in pursuing the arms traffickers, sealing conducts used by the smugglers and traders along the border. The plan also targeted the network of cartels behind this arms business. She has been at the forefront of building capacity of women peace builders in gaining necessary skills on defending women's rights, peace-making and introduction of non-violence means in solving conflicts. This initiative has managed many security-related issues.

Women have been able to encourage their husbands and sons to surrender illegal firearms. For example in Saretho location, Dadaab district, where a rogue husband who was involved in highway banditry was arrested and his firearm recovered after his wife who was trained on peace building cooperated with the government when he failed to heed her plea of voluntary surrender. Women from both Kenya and Somalia share experiences to enhance cross border peace initiatives and sensitization of dangers of SALWs. Sometimes, during violence, women from both Kenya and Somalia travel between clans to create an informal diplomacy that appealed for violence to stop and peace negotiations to open. These women always maintained communication channels and delivered messages between clans.In addition, in 1996, the Coalition for Grassroots Women Organization was formed. Members were drawn from Dadaab, Fafi and Liboi. The main agenda of this organization was to address peace building. Through this organization women negotiated with numerous warlords. Women have also been effective in mobilizing resources to finance peace meetings. In Somalia in 1994, women intervened when male clan elders failed to control rising armed teenage militia marauding around the streets. These women managed to pay for the services for both disarmament and demobilization. The Somali women have also been effective in mobilizing resources to finance peace meetings. In addition, these Somali women have also held demonstrations towards the promotion of peace in this border region and beyond.

Refugee camp leaders were very essential in both the refugee and IDP camps, since first, they link the refugee community with the United Nations High Commissioner for Refugees (UNHCR) agencies. Secondly, they are involved in conflict resolution and management in the camps. The leaders, especially the refugee community leaders play a prominent role in community peace and security. Insecurity had resulted in the humanitarian presence of response being limited to essential services only, therefore these camp leaders also play the role of aid workers.

Peace workers from both Kenya and Somalia encourage and enshrine local ownership of conflict management. They tap into local knowledge of conflict dynamics. They have been central to improvements in public security and peace. They also conduct training workshops. For instance in Hulugho, they identified the most troublesome women in the community and trained them as mediators. One of these women is the most effective mediators in the region. The peace committee workers have also trained the youth in traditional conflict resolution mechanisms to help bridge the gap between the youth and elders.

Local religious leaders on the other hand have been on the forefront in promoting peace through a number of well-received innovative initiatives. They visit several places and assist in solving insecurity. In addition, the study also established that the local religious leadership has pressured local and cross-border parties to reach accords, for instance, the accord between the Murille and Garre was reached largely due to the mediation by religious leaders in 2005. This helped to highlight Islam as a force for peace in the region. In Gedo, for example, Sharia courts have been employed to maintain the rule of law.

However, there are other actors who have inhibited the management of cross-border security relations between Kenya and Somalia. They include clan warlords, local leaders, local residents, al shabaab militia group, businesspeople and refugees. Clan warlords on either side of the border have asphyxiated much of the economy and political capacity in the region. They have exacerbated 
insecurity and tensions in the region due to their illegal arms trade and militarization of pastoralists and refugees communities in the region. The arrival of galti clansmen along the Kenya-Somalia border has been a major source of destabilizations. These clansmen, are much better armed and they are not stakeholders in local peace processes. Besides, competing clans increasingly view the control over locations as a means of establishing exclusionary zones within which they can evict or block other clans from access to pasture and business activities. This has resulted in violence among clans, thus a hindrance to the management of security relations between the two states.

Refugees have increased violence in the area. Women and children who come in genuinely as refugees have been used by militia groups to smuggle in the country illicit weapons and other illegal items.Women and children have been used to transport weapons from Somalia to Kenya. They hide these weapons under their garments so it is quite hard to retrieve them.In the camps, the refugees commit so many other crimes such as rape, armed attacks and robbery and they even have confrontations with the local residents. There have been no solutions to the crimes committed by refugees in the camps. The leaders themselves lack the support from the Kenyan government rendering the legal system within the camps largely ineffective and powerless. The absence of an effective police force at the border provides an easy way for the weapons to get into Kenya. In the refugee camps, there were conflicts between the Somali generations. The youngsters feel the elders have let them down. There are also clashes between Somali clans inside the camps, disputes between refugees and locals and quarrels within families. These conflicts among refugees are tearing families apart and they are basically rooted in Somali traditions concerning early marriages and female genital mutilation. Young refugees, many of whom were born and even raised in Dadaab and have never seen Somalia, resist such practices, while the old men insist on them.

Insecurity within the refugee camps is exacerbated by already existing clan and sub clan disparities, who in turn exacerbate criminal behavior and make for widespread insecurity both inside and outside the camps. As a result, nobody including the aid workers are allowed to move freely during the night hours due to the dangers within the camps and the possibility of crime directed towards them. This has therefore created a lawless society in the camps at night time. Some refugees were also involved in collaborating with terrorists to cause terror in the region. For example one registered refugee at the Hagadera refugee camp, hosted terrorists on the eve of the attack at Yumbis region in Fafi district. There were also three other refugees and a sheikh in Hagadera, who also played a key role in hosting terrorists that caused the attacks in Mandera in 2014, where 54 people died.

Generally refugees and IDPs within all the camps do experience violence. In Kenya for instance the refugees in most cases avoid lighting their kerosene lamps in their huts at night fearing to be attacked by fellow refugee robbers at night.

There have been frequent skirmishes and violent clashes by the pastoral communities on either side of the border over natural resource-use. Environmental degradation of pasture land has contributed to increased communal competition and pastoral conflicts over water and pasture. Moreover, the fact that Somali pastoralists have extended to the Kenyan side of the border has contributed to periodic clashes over land. In addition, the local residents compete over the new and growing urban settlements. Dadaab, has been a more immediate driver of conflict along the border. Towns and villages are important sites of trade and aid. Competition for political office among clans has in most cases turned violent. In addition, locations serve as seats of local government, conferring upon those who control them, paid positions as chiefs, assistant chiefs and control over local patronage. This has also greatly hampered the management of bilateral security relations between Kenya and Somalia.

The Al Shabaab actors has greatly inhibited the management of security relations between the two countries. The group has been involved in varied security-related issues. For instance, they have been involved in piracy activities and abductions. Piracy has been used for money laundering business along the border.In Ifo camp that 2008 and 2009, witnessed several cases of abductions. She cited a case where two nuns were abducted. One community leader told the researcher that on 13th October 2011, two Spanish MSF aid workers Blanca Thiebaut and Montserrat Serra were abducted in Ifo refugee camp while providing emergency assistance to the Somali population and their driver shot dead by al shabaab in broad daylight. Also adducted were, Judith Tebutt, Marie Dedieu, who is now dead. In addition, information from another aid worker in Ifo 2 camp also revealed that in the first half of 2011, more than 154 ships were attacked with 21 hijacked and a total of 362 people adducted along 
the border on the Somali side. The militia group has been involved in several murders within the camps and its environs. For instance, an aid worker by the name David Tebutt was murdered in 2009. On December $29^{\text {th }} 2012$, a community leader in Hagadera camp was shot several times as he entered his compound. Three days later another community leader was fatally shot in Ifo camp. Both of these men played prominent roles in Community Peace and Security Teams (CPST), a kind of volunteer police service set up several years ago. They were killed during a fight between the Kenyan police force and Al shabaab. The CPST chair for Ifo camp was shot and killed on $1^{\text {st }}$ January 2012 by al shabaab.

It was also established that that local leaders in the region had also hampered the management of security relations between the two states. The local leaders played a negative and divisive clanaffiliated politics that worsened the security situation. The region, being a heavily Somali region, most of these leaders have used the Somali speaking media to convey ill-advised messages that create suspicions within the Somali community. These Kenyan local leaders are deeply and negatively involved in Somali's dirty clan politics and as such, they are unable to play effective roles of managing bilateral security relations between Kenya and Somalia. In addition, the local leaders on the Somalia side of the border were so much clan-oriented and they cared only about the welfare of their kinsmen rather than peace within the entire border region.

Moreover, there were some businessmen who were spoilers and have exploited local tensions and blocked reconciliation efforts. Such businessmen are specifically those operating businesses which rely on humanitarian aid contracts. Some businessmen supported terrorists. For example one businessman, who runs a pharmacy in Hagadera camp, was involved in supporting terrorists. In addition, some businessmen had sneaked into Kenya illegal arms and ammunition from Somalia and this had posed a serious security threat to the region and even beyond. Besides, certain commodities such as sugar, rice pasta and electronic goods that were normally smuggled into Kenya by some unscrupulous businessmen of Somali ethnicity who are basically refugees in the camps.Most smuggling is accomplished through connivance of local leaders, including the police, Kenya Revenue Authority, Customs Officials and Kenya Bureau of Standards. These goods enter Kenya through border towns of Liboi, Mandera, Elwak, Hullugho and Wajir. The smuggling is perfected by cartels that operate from refugee camps through links with their clans in Kismayu. The refugees who are involved in these illegal businesses would then raise money and send it to their relatives in Somalia, upon receipt of money, their relatives load the required quantities of the products ordered for onto waiting lorries and trucks for onward transportation to the border points. The smugglers also bring in firearms and ammunition hidden underneath smuggled foodstuffs. As a consequence of these illegal imports of arms and ammunition, banditry has for many years become rampant in the region. Furthermore, the illegal trade of sugar, rice and electronic goods, has provided money which is believed to be funding terrorist activities.

\section{Cross-Border Security Relations Emerging From Track Three Diplomacy}

The emerging security relations from this form of diplomacy was stable.

Peace agreements between community members from both sides of the border as being the main contributor to stable security relations between the two countries. Peace accords involved noncoercive signing of agreements between community members, or members from different clans. These accords were normally signed either before or after some violence has been witnessed in the region. The decisions of signing the accords are arrived at through consensus and the accords are binding. This process of signing accords and adhering to them by the concerned parties, has contributed to stable security relations.

The signing of these peace accords is overseen by peace committees who plan activities to make space for specific confidence building meetings among clans since some clans express a fear of signing common accords as the process exposed them to tensions. The constant review of the community accords during peacetimes helped develop a culture of acceptance and collaboration among community leaders. Accords had also been signed during meetings of elders from both the Somalia and Kenyan communities. A good example is the Al Fatah declaration which was signed in April 1994, which set out guidelines on the return of peace and future relations between the cross border communities. It was also confirmed by these elders that these accords address numerous categories of security related issues, which include killings, theft and assault. The notable peace accords that had 
been signed in the region included Modogashe accord, on SALWs in 2001, Sheikh Umar Peace Accord in 2005, Sinai Peace Agreement in 2005 and Abdalla Abdwak Peace Agreement in 2005. Those involved in the signing of the peace accord always try to keep to the rules and regulations of the accord lest they face condemnation from the society.

Mediation also involves a non- coercive interaction between community members from both sides of the border, and the peace workers, religious leaders, women, youths and elders, take up the role of a third party. This process is aimed at reaching amicable relations between parties. Women are also increasingly being involved in mediation. There are currently 60 trained women who act as mediators in the region. In Hulugo, for instance, the study was informed that peace workers identified the most troublesome women in the community and one of these women is among the most effective peace mediators. Clan elders have also been effective mediators. They have been crucial in keeping the peace that exists along the border.

Generally, peace forums are very interactive. In July 2014, the local CBOs organized a peace forum among members of the Ogadan clan from both Kenya and Somalia. This meeting made them realize the common interest that they shared and as a result, they collaborated towards the construction of a maternity wing along the border. This has helped maintain community peace to ensure their assets stay operational and productive.

Peace dialogues have been extensively employed in managing security related threats such as boundary disputes, pastoral conflicts and the proliferation of illicit arms. Women are hailed for their role in dialogues since their involvement has tremendously decreased tensions in the region. they gave an example of 1994,when there was a clash among women in the market place, the women held dialogues with elders of each clan and tried to make them aware of the need to change the situation. The elders were from Garre, Marehan, Degodia, Murulle, Ajuran and Ogaden cross border clans. It is after the dialogues that in 1995, many peace groups were born, for instance, the Elders for Peace Group, the Youth for Peace Group, Wajir Peace and Development Group. Their main aim was to consolidate peace in the region. Another example that was also cited was in April to June 2010, when there was an intercommunity dialogue in Elwak. The goal was to bring together the different stakeholders to discuss on peaceful management of security threats along the border. Six peace dialogue events took place. The first dialogue attracted 120 participants from both Elwak of Kenya and Somalia. During the dialogue, the participants discussed their issues, examined their differences and agreed to move forward together to maintain peace and tranquility in the region. The second dialogue brought together all the stakeholders, including women and it ended with agreements on resource sharing. As informed by the data gathered, during this peace dialogue, one woman was quoted by one elder from Dadaab to have said that, "There are two major Somali ethnic groups living in Elwak Somalia, namely Garreh and Marehan. From today, we shall delete ethnicity from our minds and work jointly together towards achieving the common objective and goal of strengthening peace among ourselves. We cannot achieve development without peace." As a result of this intercommunity dialogue, there has been ease of movement among the cross border communities. The resources are being shared without resorting to violence. Instead of being divided across the border, communities are reaching out to each other.

Peace activities were also viewed as very essential to stable security relations. Some of the peace activities that were mentioned by the respondents included, joint town cleanups and football tournaments, peace choirs and dances and peace dramas. These interactions during such joint peace activities eased tensions, led to the exchange of ideas, making communities appreciate each other and thus enhance peaceful co-existence. In other instances, cross-border communities got involved in coowning or co-managing peace projects. This has led to an increase in confidence and interaction and access to services such as hospitals, livestock and schools by the Somali citizens. During sports, the youths interact and share ideas. It is through this interaction that some youths have given up their arms and stopped engaging in criminal activities. This thus has contributed to stable security relations. Sports have been a useful entry point for social change as they represent a tool to mobilize, empower and engage young people to do just that. Sports have taught the youth and other community members about conflict resolution, fair play and communication leadership. Sports have changed the behavior of young people by helping them to break the vicious cycle of violence. 


\section{CONCLUSION AND RECOMMENDATION}

Track Three diplomacy has proven to be effective in managing security relations between countries since it involves the grassroots actors who understand the root causes o the conflicts and hence are in a better position to resolve the insecurity in the region. It is thus recommended that Track Three is embraced in the high diplomatic circles since it has proven to be more effective in managing relations where other forms of diplomacy failed.

\section{REFERENCES}

Ahmed, Samina. (1998): Diplomatic Fiasco: Pakistan's Failure on the Diplomatic Front Nullifies its Gains on the Battlefield. Belfer Center for International Affairs: Kennedy School of Government.

Atieh, A, Ben, Nun, G, El Shahed, G, Tahlliu, S. (2004): Peace in the Middle East and the IsraelPalestinian Conflict. Geneva.

Bosworth,B,Collins, S, Lusting, N. (1997): Coming Together? Mexico-US Relations. Washington DC: Brookings.

Handelman, S. (2012): "Two Complementary Settings of Peacemaking Diplomacy: Political Elite Diplomacy and Public Diplomacy. Diplomacy and Statecraft. 23:1, 162-178." Israel-Palestine Center for Research and Information. Official website.

Lederach, J,P. (2003): Conflict Transformation. NewYork: Good Books.

McDonald, J,W. (1991): "Conflict Resolution Consortium Article: Futher Exploration of Track 2 Diplomacy in timing the De-escalation of International Conflicts". Ed. Lois.

McHale, J. (2009): "Project on Middle East Democracy". Washington DC.

Menkhaus, Ken. (2005): "Kenya-Somalia Border Conflict". Nairobi, Kalson Towers. Repot for the US Agency for USAID. Contract No. 623-1-00-03-0050-00. Nairobi: USAID.

Mngqibisa, K, Solomon, H. (2000): "Toward Conflict Transformation in the Democratic Republic of Congo with Specific Reference to the Model of Kumar Rupesingle". Strategic review of Southern Africa 22.

Payne, J,G. (2009): "Reflections on Public Diplomacy: People to People Communication. American Behavioral Scientist 53: 4. 579- 606.

Saunders, H,H. (1999): A Public Peace Process: Sustained Dialogue to Transform Racial and Ethnic Conflicts. London: Macmillian.

Shemesh, A. (2012): "Citizen Diplomacy: Creating a Culure of Peace: The Israel-Palestinian Case". Israel Journal of Politics, Economics and Culture 2:3, 58-69.

Thorntorn, E,A.(2003): The Changing Contours of Diplomacy. New Delhi: WISCOMP.

Turton, E. (1974): Bandit or Patriot: The Kenyan Shifta War 1963-1968. Berkeley, C.A: University of Carlifornia Press.

Zhu, Z.) 2015): "people-to-People Diplomacy in China-Japan Relations". The Diplomat: The diplomat.

\section{AUTHOR'S BIOGRAPHY}

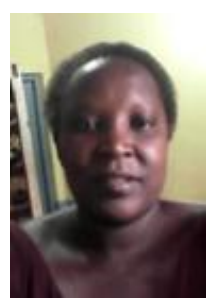

Stella Wasike, a PhD candidate in the area of Diplomacy and International Relations. She is also a holder of a Masters degree in Diplomacy and International Relations. Am fluent at English and French. Am currently a teacher in a girls school and also a head of the language department. 